REVISTA DE DERECHO UNED, NÚM. 13, 2013

\title{
EL SANTO OFICIO EN CUENCA. LA RELACIÓN DEL AUTO GENERAL DE FE DE 1583
}

\author{
THE HOLY TRADE IN CUENCA. THE RELATION OF THE \\ GENERAL CAR OF FAITH OF 1583
}

\section{EULOGIO FERNÁNDEZ CARRASCO}

UNED

Resumen: La delación fue la manera habitual que utilizó la Inquisición para condenar a los culpables de práctica de los delitos de herejía. A partir de aquí, los interrogatorios, la cárcel, el tormento y las penas funcionaban para el desarrollo del acto final, que era el Auto de Fe. Reseñar la importancia del Auto de Fe como la ceremonia pública de ejecución de personas condenadas por la Inquisición acusados de herejía y otros delitos. El Auto de Fe era la más impresionante de las ceremonias del Santo Oficio celebrada con gran pompa y solemnidad. Se fundamentaba en una procesión de los condenados, conducidos a una plaza pública, generalmente la plaza mayor, la pronunciación de un sermón y seguido de la ejecución de la sentencia en la que podía haber condenados en la hoguera, función que realizaba el brazo secular. Estas ejecuciones se realizaron tanto en los territorios de España y Portugal como en sus colonias.

Abstract: The delation was the habitual way that used the Inquisition to condemn the culprits of practice of the crimes of heresy. From here, the interrogations, the jail, the torment and sorrow were working for the development of the final act, which was the Auto-da-fé. To outline the importance of the Auto-da-fé as the public ceremony of persons' execution condemned for the Inquisition accused of heresy and other crimes. It was the most impressive of the ceremonies of the Holy Trade celebrated with great pomp and solemnity. The major square was based on a procession of the repro- 
bates, led to a public square generally and on the pronunciation of a sermon, followed of the execution of the judgment, in which it could have condemned in the bonfire, function that realized the secular arm. These executions were realized both in the territories of Spain and Portugal and in his colonies.

Palabras clave: Inquisición, Auto de Fe, familiares, sambenito, relajado.

Key Words: Inquisition, Auto-da-fé, relatives, sambenito, relaxed.

Recepción original: 05/11/213

Aceptación original: 27/11/2013

Sumario: I. Introducción.-II. Documentación.-III. La Relación del Auto de Fe. Noción y misión publicista.-IV. El Auto General de Fe y su desarrollo.-V. El Auto Público de Fe de 6 de Agosto de 1583.-VI. Conclusiones.-VII. Apéndice.

\section{INTRODUCCIÓN}

La publicación de la Relación de este Auto que estudiamos y que se desarrolla a finales del siglo XVI, se produce en un periodo en lo que respecta a esta institución llamada Inquisición, en donde el Auto de Fe se desarrolla de la forma más majestuosa y donde se busca la mayor publicidad del mismo. Ello se desprende de las Relaciones de Autos y la correspondencia entre el Consejo y los diversos tribunales provinciales inquisitoriales en este periodo. El Inquisidor General Gaspar de Quiroga (1573-1594), cardenal y arzobispo de Toledo, opta por un endurecimiento de las actuaciones de los diferentes tribunales del Santo Oficio en contra de lo que hasta ese momento venían haciendo sus predecesores.

Con Felipe II, al igual que ocurre con Carlos I, la Inquisición sigue una misma línea de dureza y se asiste a uno de los periodos de mayor rigor inquisitorial, es una institución intimidatoria en manos de la monarquía donde se produce una gran politización de la Inquisición (caso de Antonio Pérez) donde Felipe II manipula la Inquisición a su servicio debido al momento débil de esta institución y de su Inquisidor General, pues no olvidemos que en el año 1591, la actividad o iniciativa inquisitorial no existe y tanto en Aragón como en Cataluña, la Inquisición es más virtual que verdadera.

Se reforma el proceso y el derecho penal para asegurar el proceso inquisitorial y reforzar al tribunal, ¿de qué forma? pues aumentan- 
do la discrecionalidad de los jueces y disminuyendo las garantías del reo. La práctica de los tribunales inquisitoriales, fue creando un proceso penal especial, más duro y muy temido, incluso más que el de la justicia ordinaria, motivado por el tormento, el secreto y la infamia personal y familiar de los reos. Con Felipe II se procesan a grandes personajes (el arzobispo de Toledo Bartolomé de Carranza, Fray Luís de León, encarcelado durante cuatro años entre los años 1572-1576) y gran número de personas, según ha publicado García Cárcel (aproximadamente 25.000) siendo, los moriscos (unos 8.000), las proposiciones heréticas (8.000), los luteranos (2.000) y los judaizantes (1.500) su gran persecución. En resumen, la segunda mitad del XVI, sirve a la Inquisición para dedicar su actuación de control a la vida familiar y social y en la década de los ochenta de este siglo es donde se acentúa más el sistema represivo de esta institución.

Este Auto aunque se celebra más de un siglo después de la instauración del Santo Oficio en España y, por ello, se estime muy apartado en el tiempo de la etapa fundacional, lo cierto es que el Auto General de la Fe de 6 de Agosto de 1583, constituye un acto en el que aparece, prácticamente, casi toda la tipología delictiva dentro del campo de actuación que poseía el Santo Oficio en esos momentos. Con el desarrollo de este Auto como el de otros, la Inquisición lo que pretende es demostrar su poder.

El lector encontrará con el estudio de este artículo, argumentos para las respuestas a tales interrogantes de una institución, que a nivel universal, ha representado el símbolo de la intolerancia, del aplastamiento de la libertad de pensamientos en nombre de la fe, del terror y la coacción. No deja de sorprender que las grandes figuras y los máximos exponentes de la espiritualidad de la vida española o sus renovadores, los educadores de la juventud, hombres y mujeres populares y eminentes, fueran molestados y la mayor parte de ellos procesados por la Inquisición.

Para darnos una idea de la mencionada actividad del tribunal conquense, basta con fijarnos en los Autos de Fe habidos entre 1583 y 1600, aunque su mayor auge se produce entre los años 1560-1570, con algo más de 880 conquenses. Se conocen relaciones de los autos celebrados en los años 1512, 1517, 1531, 1554, 1556, 1558, 1559 y 1568 y 1583; los autos de 1586 en la catedral; el auto público de 1590; el auto público en la catedral de 1593 pese a tener relajados y el auto público de 1596. En ellos, queda reflejado el número de judaizantes que fueron procesados, moriscos, luteranos y otros (fornicadores, blasfemos y proposiciones). Se puede sintetizar que en el 
siglo XVI, los autos son todos generales y desde mediados y finales del XVII, casi todos los autos son particulares celebrados en iglesia incluso con relajados.

\section{DOCUMENTACIÓN}

La labor desarrollada por el Santo Oficio en Cuenca la tenemos reflejada en el Archivo de la Inquisición de Cuenca, situado en el Archivo Diocesano Conquense, El tribunal inquisitorial conquense fue más conocido por los personajes que se traían a esta ciudad desde poblaciones cercanas a él como por ejemplo Madrid y Toledo, que la actividad propia contra los habitantes conquenses. El Santo Oficio de Cuenca no destacó a lo largo de su historia por ser un tribunal importante y acaudalado; pero su cercanía a la Corte, hizo que a él fuesen remitidos los procesos de relevantes personajes. En estas líneas se aprecia la estrecha vinculación familiar, económica y social que existía entre los principales judaizantes del distrito y sus correligionarios de Madrid ${ }^{1}$.

La consulta de un manuscrito sobre la Relación de un Auto de $\mathrm{Fe}$, entendiéndola como la exposición o descripción en el que se da cuenta de la aclamación del Auto, es decir el relato de la celebración del mismo, nos da cuenta de la misión fundamental propagandista que tiene la Relación asociada al Auto de Fe, entendiendo éste como ceremonia y la Relación como relato.

Pues bien, el relato de un Auto General de Fe en un antiguo manuscrito, nos hará revivir un proceso de curiosa estructura jurídicoprocesal. Gracias a estos documentos, los investigadores queremos hacer una luz para descubrir el conocimiento de una época en que las actuaciones del Santo Oficio respondían a una intransigencia religiosa influenciada políticamente, en donde cualquier desviación suponía tener un pensamiento heterodoxo que debía ser severamente castigado. No se trata de una leyenda o tradición oral, estamos ante un caso real, un proceso inquisitorial a unas personas, donde son juzgadas y condenadas.

La documentación sobre la que se basa este estudio está recogida en el Archivo Diocesano de Cuenca. Concretamente en la sección Inquisición, libro 339, ff. 222-225, con el título Auto General del año

1 De LERA GARCIA, R., "La última gran persecución inquisitorial contra el criptojudaísmo: El Tribunal de Cuenca, 1718-1725», en Escudero, Perfiles jurídicos, ob. cit., p. 806 . 
El Santo Oficio en Cuenca. La relación del Auto General de Fe...

1583. Relación del orden que se tuvo en el Auto que se celebró a 6 de agosto de la Transfiguración, año de 1583.

De igual manera se encuentra información de las causas del año 1583 (desde el día 6 de agosto) en el Archivo Histórico Nacional, Secc. Inquisición. Leg. 1931. Exp. 6

Para un estudio sobre el tribunal conquense desde el ámbito inquisitorial, puede consultarse en AHN. 1. Inquisición. Guía sumaria, pág. 12: Tribunal de Cuenca.

\section{CUENCA}

Cartas al Consejo, expedientes y me- 1563-1820 Legajos 2544 a moriales. 2601

Hacienda, expedientes de obras, cuen- Siglos XVI-XIX Legajos 4536 a tas de canonjías, confiscaciones, depositaría, juntas de hacienda, salarios y 4545 ayudas de costas, receptoría, remisión Libros 10, 57 y 58 de fondos al Consejo, rentas, censos, secuestros y varios.

Registro de cartas y despachos expedi- 1635-1807 Libros 628 a 634 dos por el Consejo para los Inquisidores del Tribunal de Cuenca.

Relación de causas de Fe.

Pleitos civiles.

Pleitos fiscales

Pleitos pendientes

Pleitos criminales

Procesos de Fe

Visitas.

Varios.
Siglo XVII Legajo 1931

Siglos XVI-XVII Legajos 1915 a 1918

Siglos XVI-XVII Legajos 4530 a 4535

Siglo XVI Legajo 1934

Siglos XVI- Legajos 1919 a XVIII 1929

Siglo XVI Legajo 1930

Legajo 1933

Legajos 1935 a 1937

\section{LA RELACIÓN DEL AUTO DE FE. NOCIÓN Y MISIÓN PUBLICISTA}

La Relación es la exposición o descripción en el que se da cuenta de la aclamación del Auto, es decir, el relato de la celebración del mismo. Las Relaciones, suelen tener muchas deficiencias, como por 
ejemplo, las múltiples omisiones y saltos que producen en algunas de las ceremonias que conforman el Auto de Fe. Las Relaciones de Autos apenas hablan de los tablados de los reos, debido a que el reparto de sus gradas es siempre la misma en todos ellos y que son distribuidos por los tribunales, en donde sólo resaltan las autoridades asistentes como pueden ser el Alguacil Mayor o el Alcalde de presos. En las Relaciones de Autos se suelen señalar con insistencia, los asientos y los adornos de los elementos que conforman el escenario y en especial el presbiterio el cual se recubre de damasco carmesí.

La misión fundamental publicista de la Relación asociada al Auto de $\mathrm{Fe}$, entendiendo éste como ceremonia y la Relación como relato, es la comunicación de masas que se produce tanto en el asistente al Auto como al lector del relato mediante su imaginación y lectura (por ejemplo los europeos viajeros que venían a España) y que sirve para conseguir lograr una auténtica unanimidad de creencias religiosas y políticas. En síntesis, son los medios publicitarios que pasan a engrosar la vida urbana y rústica.

\section{EL AUTO GENERAL DE FE Y SU DESARROLLO}

El Auto de Fe es una fiesta popular y festiva que reunía un orden social, político y religioso en cuya celebración, muy costosa por cierto, se requería una gran organización, llegándose a producir lo que se ha venido en llamar afirmación de la fe católica junto a la del Estado y el orden social establecido. El Auto de Fe es la lectura pública de las sentencias pronunciadas por los inquisidores en presencia de los acusados y concurriendo las grandes autoridades. En este mismo acto se entrega al verdugo a los condenados a muerte. Eran por otra parte, la ocasión para que el pueblo pudiera contemplar todo el aparato ceremonial y el poder del Santo Oficio y del $\mathrm{Rey}^{2}$, pues algunos estaban presididos por él. El Auto de Fe es un acto solemne que se organizaba tras la acumulación de varios procesos con misa, sermón y lectura de las sentencias a los penitenciados y con gran asistencia de público y autoridades. En conclusión, es la ceremonia emblemática de poder del Santo Oficio.

2 Para Pérez Marcos, ya en tiempos de los Reyes Católicos, éstos, [...] impusieron un monopolio ideológico que se manifestó en la implantación de un único modelo de sociedad en la que el poder civil y el inquisitorial se apoyaban mutuamente, de tal manera que la Inquisición se convirtió en un instrumento político por medio del cual el estado podía perseguir a todas aquellas personas que obstaculizaran los intereses del gobierno. PÉREZ MARCOS, R. M. ${ }^{\text {a }}$ ob., cit., p. 183. 
Escudero opina que el Auto de Fe suponía una eclosión pública de una Inquisición espectacularmente secreta. Conforme los autos fueron adquiriendo publicidad y formalidades, la liquidación del proceso se convirtió en una fiesta dramática donde la religiosidad, el fanatismo, la curiosidad y la compasión se dieron cita en un pueblo agitado por tales acontecimientos ${ }^{3}$.

El resumen que se puede hacer sobre el Auto de Fe podría ser el siguiente: En torno a quince o treinta días antes de la fecha de celebración del Auto, que se hacía coincidir con un domingo o festivo, se publicaba, valiéndose para ello de la lectura de un pregón por toda la ciudad y comunicándose a las autoridades la invitación a su asistencia. Durante este tiempo anterior a la celebración se va preparando todo el escenario, que consiste en un tablado de madera con gradas a distintas alturas, situado, en el caso de los Autos Generales, en una plaza pública. La tarde anterior a la celebración de la ceremonia, la procesión de la Cruz Verde recorría las calles y en ella desfilaban en primer lugar los soldados de la Zarza, seguidos de los Familiares de la Inquisición que portaban el estandarte. Posteriormente los integrantes de las órdenes religiosas, que llevaban velas en las manos y cantando el miserere. Por último se situaban las autoridades municipales y eclesiásticas.

En la madrugada del día de celebración del Auto, se les notifica a los reos la sentencia y se les imponen las insignias según la condena. Los encargados son el Inquisidor, el Secretario y el Alcaide ${ }^{4}$. Según la pena a que habían sido condenados, así salían a la procesión. Primero los condenados en estatua por estar muertos o ser fugitivos, representadas sus figuras en papel y cartón, con sambenitos y corozas y con sus nombres escritos en el pecho. Algunas de estas figuras, en el caso de los condenados fallecidos portaban arcas con sus huesos. Después aparecían los relajados o condenados a muerte, vestidos con un sambenito (pintados de llamas y diablos) y una coroza; detrás se situaban los reconciliados con sambenito rojo con la cruz de San Andrés y detrás los abjurados, con velas amarillas apagadas en las manos, corozas y sogas en la garganta con la cantidad de nudos se-

\footnotetext{
3 ESCUDERO LOPEZ, J. A., «La Inquisición Española», Historia 16, especial 10 Aniversario, 1986, pp. 13-14.

4 Alcaide: Su misión era el control de las celdas y también el cuidado de los presos. Se encargaba de recibir a los detenidos por los alguaciles, debiendo registrarlo en el correspondiente libro y anotar cuidadosamente la ropa que llevaban consigo los reos así como las cosas que les eran proporcionadas durante su prisión. Estaban obligados a mantener incomunicados a los presos. Cuando estos comparecían en la sala de audiencias eran conducidos por él, quien también se encargaba de su retorno, salvo disposición en contrario de los inquisidores.
} 
gún los azotes a recibir. Algunos de los reos podían ir amordazados y con las manos atadas. Cuando la procesión llegaba al lugar donde se celebraba el Auto, se colocaban los asistentes en un tablado con gradas a diferentes alturas, en las que permanecían inquisidores, autoridades y reos durante todo el tiempo.

El Auto comenzaba con una misa que solía durar todo el día. En el sermón, se realizaba el juramento de todos los asistentes, prometiendo luchar contra la herejía y se procedía a la lectura de las sentencias. Los condenados a relajación eran entregados a la justicia seglar que los conducía al quemadero, para que se procediese a su muerte en la hoguera, garrote u horca, estos dos últimos en el caso de que existiese arrepentimiento previo. El quemadero se solía situar a las afueras de la ciudad. Posteriormente se celebraba la abjuración de los condenados a esta pena, que podía ser de leví, si se trataba de una sospecha leve de herejía o de vehementí, en el caso de sospecha plena. La abjuración es el arrepentimiento por los errores cometidos, retornando a la Iglesia y estando dispuesto al cumplimiento de las penas impuestas por el tribunal. Una vez leídas las sentencias proseguía la misa y se encendían las velas de los condenados. Tras finalizar la misa concluía el Auto de Fe y los reos penitenciados volvían a la cárcel del Santo oficio para cumplir la condena.

\section{EL AUTO PUBLICO GENERAL DE FE DE 6 DE AGOSTO DE 1583}

\section{Licencia para celebrar Auto de Fe}

El permiso para la conmemoración del Auto nacía con la petición que realizaban los tribunales de distrito al Consejo de la Suprema, solicitando la correspondiente licencia para ello, enviando al mismo tiempo, los procesos para que vinieran a ser revisados por este alto organismo.

En el caso presente, el tribunal conquense, escribe al Consejo, solicitando licencia para la celebración del Auto en la forma que tenía ordenado el alto tribunal. En su contestación, la Suprema, les pide que le digan desde el tribunal conquense, el número de causas que habían pendientes y sobre qué versaba el contenido de las mismas. Al mismo tiempo le ordena al Santo Oficio de Cuenca que un vez respondido, hiciesen publicación del Auto, señalando el día que había 
de celebrarse, pero con la condición de que le fuera comunicado al Consejo conforme estaba ordenado por el mismo.

Se conoce el caso del año de $1568^{5}$, donde el tribunal conquense, entre los presos que tiene en la cárcel inquisitorial (4 relajados entre ellos) y las causas pendientes de tramitar, solicita por escrito al Consejo de la Suprema Inquisición el permiso para la celebración de un Auto de Fe como consecuencia de los gastos que originan los presos y debido a que las causas prácticamente las tienen acabadas. Contra esta decisión o determinación de celebrar auto de Fe, se opone de forma categórica el Consejo al contestar al tribunal conquense (27 de abril) sobre el sitio de celebración, motivado por la presencia de relajados ${ }^{6}$ en el auto y que cumpliese así lo establecido por la Supre-

5 Carta para Cuenca de 25 de abril de 1568. Lib. 5 de la Secretaria de Castilla. Quanto a lo que escrivis que de once a doze causas que en este Santo Oficio ai pendientes, están votadas las mas de ellas, y por excusar el gasto que los presos hacen, teneis determinado celebrar Auto de la Fe en la iglesia mayor de esa ciudad, parece que vos el dicho licenciado Francisco de Ayanz debeis advertir a vuestro colega que si tiene algunas causas de su instancia, vos las imbie para celebrar dicho Auto. Y aviendo de salir a el persona relaxada, lo celebrareis en la Plaza y no en la iglesia mayor como antes de ahora os esta ordenado y avisarnos del dia que se hubiere de celebrar. Señores D. Busto de Villegas=Soto=Vega. Esta registrada en el folio 190, lib. 5 , num. 1.

BN. Mss. 5760, ff. 120-120 vto.

6 Carta del Consexo para Cuenca a 27 de abril de 1568 y acuerdo de salir en el Auto Particular persona relaxada como decis, la celebrareis en la Plaza y no en la iglesia como antes de ahora esta ordenado. Lo contrario tiene Horacio. Y en la carta acordada de 4 de septiembre de 1657, se ordena saquen las iglesias las estatuas de relaxados con tal que la entrega de justicia secular se haga fuera del cementerio y aunque no sean relaxados en persona en quanto a este punto, no es larga la diferencia.

Si el Corregidor se ha de hallar presente al Auto o bastará estar en una parte señalada para la entrega o le podrán obligar a ello? Las sentencia de relaxados parece ser que se deben publicar estando presente la xusticia secular a quienes se entregan porque como no tiene conocimiento de la causa por ser materia ecesiastica, ni le pueden manifestar los meritos para que xuzgue por ellos el secreto y por ser incapaz, de aquí viene haberse de hallar presente para oírlos y la declaración que haze el santo Oficio de su sentencia como en caso notorio conforme a las leyes reales que entonces tienen lugar y no antes, Peña sostiene que esto no sucedería estando ausentes.. Y lo mismo se halla dispuesto por la carta acordada referida de 4 de septiembre de 1567 y se coadyuba con otra carta deel Consexo de 1582 para Cuenca. Y si el Corregidor se excusare de ir acompañar el Auto y asistir a el prozedereis contra el por censuras con buen modo.

Pero no obstante se puede pronunciar la sentencia, aunque el juez secular no este presente. Peña opina así. Y bastara intimarle al juez secular por medio de un notario del secreto como que esta declarado por el Santo Oficio por herege y se hara por escrito la notificación y la entrega que es lo mas seguro. Asi opina Peña.

Y a lo que se dice en contrario se responde que podrá el que tiene jurisdicción ordinaria no guardar el modo y sin embargo valdra el acto y lo mismo podrán los Inquisidores por equipararse su jurisdiccion a la ordinaria y aun es mayor porque representan al Pontifice delegante. Y de esta opinión ai un responso que el cardenal 
ma. Igual ocurre en el año 1582. Suceso que ya se había producido por otra carta dirigida al tribunal de Cuenca en 1537 en donde se establece la obligatoriedad de su celebración en la plaza y la prohibición de hacerlo en la Iglesia, si al auto concurren relajados. La petición del tribunal conquense, está basada en la existencia de tener pendientes once o doce causas, las cuales estaban votadas la mayoría de ellas y por excusar el gasto que los presos hacen al Santo Oficio se tenía determinado celebrar Auto de Fe en la Iglesia Mayor. El Consejo les contesta argumentando que puesto que había que salir a él persona relajada, debía de celebrarse en la plaza y no en la iglesia mayor como anteriormente estaba ordenado ${ }^{7}$.

Silneto mostro a Peña. Y a las cartas del Consexo responde que miran a lo mejor y lo mas conveniente y no es dudable que lo seria que asistiese el Corregidor, pero no por eso es precisamente necesario, ni el Consexo pone de necesidad y se conoce en que algunas ocasiones no a asistido y se a pasado por ello como en Cuenca año de 1611. Madrid y mayo 4 de 1664.

BN. Mss. 5760, ff. 120-120 vto.

7 AHN, Inquisición, lb. 1231, p. 160. AHN, lb. 352, p. 190.

En la BN hemos encontrado unas orientaciones que da el Consejo a los tribunales provinciales en cuanto a la existencia de personas relajadas en los Autos de Fe y es como sigue:

Auto de Fe en que sale persona relaxada. Puntos acerca de la celebración de Auto de $\mathrm{Fe}$.

Si se podrá celebrar en dia de fiesta y si en Autos Particulares se podrán relaxar reos o a de ser precisamente en Auto General? Si el Auto Particular en que ai persona relaxada se podrá celebrar en la iglesia y donde se ha de hazer la entrega.

Si el Corregidor se ha de hallar presente al Auto para la entrega deel relaxado, o se le podrá entregar estando en parte señalada y si puede ser obligado a uno u otro

1. Si se podrá celebrar en dia de fiesta? Americo tiene que no se puede en 3. p. de nono, modo terminandi processum, num. 197, vers. qui bus die non festiva, fol.110, num. 200, fol. 512.

Lo contrario tiene Peña y opina que se puede celebrar en dia de fiesta, 3. P. om 25, pers quod die tali et seqq, fol. 512. Paramo, lib. 3, q. 4, num. 36, fol. 593 y varios autores más. Y así se practica en España y esto no viene a ser materia de duda. Pero en Italia el juez secular no ejecuta el castigo en día festivo. Peña 3. fol, 562.

2. Si se podrá relaxar un reo en Auto Particular? No ai disposición de derecho, instrucción, ni Carta Acordada en que se disponga que ara de ser precisamente en Auto General y asi es arbitrario según la ocurrencia aunque a sido estilo en España que se haga Auto Particular, digo en Auto General conque algunas vezes conviene despachar los relaxados en Autos Particulares, como sucede en la Inquisición de Cuenca, año de 1568 y parece por carta del Consexo de 27 de abril de 1568 y en el de 1611, se relaxaron quatro personas en dicha Inquisición en el Auto Particular que se celebro en el claustro de la iglesia catedral y finalmente por carta acordada de 4 de septiembre de 1657, esta ordenado que las sentencias de relaxados en estatua de difuntos o fugitivos se pueden pronunciar en Autos Particulares.

Si el Auto Particular en que ai persona relaxada se podrá zelebar en la iglesia? Americo tiene que no, num. 197, ver. quince, fol. 510, num. 198, v. 200.

BN. Mss. 5760, ff. 118vto-120. 
Sin embargo, en el Auto de 1611 donde fueron relajados varias personas, el Auto se celebró en el claustro de la iglesia catedral que era lugar sagrado, siendo contestada la comunicación del tribunal conquense por Carta Acordada de 1611 en el sentido de que tras recibir una petición de licencia por la que avisaban al Consejo de que habían acordado celebrar Auto Particular en la iglesia catedral con los relajados que había y la intención de no convidar al Corregidor, le había parecido al Consejo un gran inconveniente y novedad celebrar Auto en la iglesia existiendo relajados ${ }^{8}$. Esta recomendación de la Suprema surtirá efectos en el tribunal conquense debido a que en lo sucesivo y según lo ordenado, en los Autos de Fe que celebra el Santo Oficio en Cuenca, se llevan a cabo en la Plaza Mayor y cuando no existen relajados, la celebración se produce en la catedral.

\section{Convocatoria del Auto de Fe. Notificación a las autoridades. Normativa sobre la convocatoria del Auto de Fe}

Lo usual en cuanto a la comunicación, es que en Castilla, la notificación se lleve a cabo por el Fiscal y el Secretario del Santo Oficio.

Una vez recibida la licencia ${ }^{9}$ y examinados los procesos, se congregan los inquisidores y los oficiales del tribunal en la Sala del

8 AHN., lb. 587, p. 14.

9 Sobre estos requisitos puede verse en la BN, respecto al tribunal de Zaragoza, lo siguiente:

Autos de Fe. Licencia, formas y lugares.

Que no envíe el nuncio con las Relaciones de los Autos de Fe al Consejo de 5 de septiembre de 1592 .

Que se informe al Consejo del lugar que llevan los oficiales y demás ministros que concurren en los Autos de Fe y otras concurrencias de 8 de febrero de 1625.

Que avisen uno o dos días antes al Virrey y al Arzobispo de Zaragoza cuando hubiese Auto de 9 de febrero de 1562. Y otra de 28 de febrero de 11582 que estando ausente el señor obispo se le envíe el aviso de suerte que pueda saberlo un día antes.

Que uno de los Consultores lleve el estandarte por faltar el Fiscal de 31 de marzo de 1586 en Zaragoza.

Que habiendo relajados no se haga Auto (aunque sea sodomítico) en iglesia sino dentro de la alhaja por haber pocas causas de Auto de 10 de septiembre de 1610 .

Que después de hecho el Auto leída la sentencia a alguno, entregado a la justicia seglar, se deje hacer su oficio a los confesores se ha de enviar carta de ello al Tribunal de 21 de octubre de 1620.

Los Autos de Fe se harán en día de fiesta por el escarmiento que causa, Salcedo en Práctica crimin y que no se haga en día de fiesta habiendo relajados.

Que no se hagan Autos impresos para poner en los procesos de 20 de septiembre de 1590. En Logroño se dio licencia para las causas de brujas por ser muchas en el año 1611, se imprimieron curadurías y abjuraciones.

BN. Mss. 5760, fol. 147. 
Secreto y coordinan los planes de la convocatoria para la posterior comunicación a las autoridades y la publicación del Auto de Fe.

En este Auto de Fe se relata que el miércoles 26 de julio, a las dos de la tarde, con las órdenes de cómo se quería hacer la publicación, se envió al Fiscal para comunicárselo al obispo y posteriormente al Cabildo. La comunicación a los marqueses de Cañete, la efectúa el Alguacil. Por último, el Receptor es el encargado de comunicárselo al Ayuntamiento. En otras ocasiones, sin embargo, es el Receptor, por reunir en él la condición de regidor más antiguo, el que lo comunica al marqués de Cañete y el Alguacil, lo traslada a las autoridades civiles

La preceptiva del Auto de Fe sobre esta materia la podemos encontrar en las diferentes instrucciones que contienen las Cartas Acordadas del Consejo. La Carta Acordada, es la redactada por el Consejo de la Suprema y que envía a los tribunales de distrito en la que manda hacer u omitir algo en los casos que ocurran de competencia en asuntos del Santo Oficio y la que obliga como si fuera ley interior. Son unas circulares manuscritas y de las que existe obligación por parte de los Inquisidores de guardarlas y archivarlas y luego reunirlas en un apéndice a las instrucciones impresas. Se enumeraron de forma cronológica. La primera Carta Acordada que se conoce es de fecha 2-12-1513 que trata sobre asuntos de presos y sambenitos. La denominación de Carta Acordada no aparece hasta la de Fecha 30-9-1572 (número 71 que trata sobre información de Inquisidores). Hasta esa Fecha se les denomina por el Consejo con nombres como se ha acordado (1543) o como nuestra provisión (1547) o como lo proveído (1553).

Respecto a las normas dadas para el desarrollo de este Auto quedan reflejadas de la siguiente forma: En la Relación se dice que el viernes 5 de agosto, a las tres de la tarde, acudieron al Santo Oficio los Familiares de él y en donde el Inquisidor Jiménez de Reynoso les habló y encomendó el buen orden y sosiego que debía regir el Auto, señalando a cuatro Familiares, para que al día siguiente vigilasen el tablado y la puerta. Para ello, les ordenó que acudiesen al día siguiente por la mañana temprano para entregarles las varas y así poder gobernar la procesión. Asimismo encomendó a tres o cuatro de ellos, que eran considerada gente honrada, para que estuviesen también el día siguiente en las entradas de la plaza y no dejar entrar en ella a ninguna persona a caballo o que portara armas, conforme al contenido del pregón que se había dado. 
Es curioso observar la actitud que emplean los Corregidores en no colaborar en los Autos de Fe con relajados, esto lo vemos en lo acontecido en Cuenca en 1582, por lo que el Consejo en Carta instituye que si el corregidor se excusare de ir a acompañar al Auto y asistir a él, se procediese contra él mediante censuras hechas de buena forma, pero no obstante se podía presentar la sentencia, aunque el juez secular no estuviese presente, y bastaría invitar al juez secular por medio de un notario, pero haciéndose por escrito la notificación y la entrega que era lo más seguro ${ }^{10}$.

\section{Publicación del Auto General. Pregón}

Los preparativos del Auto de Fe, comenzaban con la publicación de la fecha de su celebración, que se hacía con una antelación que oscilaba entre ocho, quince o treinta días, procurándose que la celebración coincidiera con un domingo o un día de fiesta, generalmente religiosa, o feria, días en los que existían ciertas prohibiciones o concesiones, como por ejemplo, llevar armas o la de otorgar indulgencias a los asistentes por un periodo de cuarenta días.

El medio utilizado para la conmemoración del Auto es el pregón. De todo ello se pasaba comunicación para informar a las autoridades y se les invitaba a la asistencia del mismo. Se procedía a leer un pregón por la ciudad dando comienzo los preparativos para su celebración que generalmente ocurría en la plaza o en el interior de las catedrales. Si se realizaba en la plaza, en ésta, se levantaba un ca-

10 Carta para Cuenca de 6 de febrero de 1582. Muy Poderosos Señores. Recivimos vuestra carta de 3 del presente, y en lo que toca al entredicho y cexación a Divinis, que decís, está puesta en esa ciudad, por lo cual el cadalso de esa santa iglesia, no podrá hacer con el Santo Oficio al tiempo de celebrar el Auto lo que a acostumbrado; a parecido que con buenos medios procuréis señores con la persona que a discernido las dichas o suspender censuras y zesación, las alze para el dia del Auto, y si no viniese en ello haréis el Auto mejor pudieredes o suspenderlo para otro dia sin intrometeros en proveher cosa alguna, en razón de alzar por vuestra autoridad las dichas censura y zesación.

Hemos visto lo que escrivis, os a imbiado a decir el Corregidor cerca de la asistencia y acompañamiento del Auto, y a parecido que según la costumbre que hasta ahora ha venido en esto, y si el dicho Corregidor se excusare de ir acompañar el dicho Auto y assirtir en el, procedereis contra el por censuras con buen termino.

En lo que toca al recado que el Corregidor enbio Pedro Perez notario de el secreto de el Santo oficio con un Alguacil, a perecido se excusen semejantes ocasiones. Madrid y febrero 6 de 1582 .

Folio 111 del libro de cartas de la Secretaria de Castilla desde el año 1580, hasta 85, lib. 9.

BN. Mss. 5760, ff. 120-120 vto. 
dalso de considerable dimensión y sobre él se levantaban dos o tres tablados con gradas en donde se colocaban a distintas alturas, los inquisidores, las autoridades y los reos.

La forma de dar el pregón en esta Relación, se describe diciendo, que una vez que el Fiscal y el Receptor, habían cumplido los encargos de la publicación del Auto, a las cuatro de la tarde salieron del Santo Oficio más de 20 Familiares a caballo, a los que se habían apercibido por la mañana, cerrando el desfile el Alguacil que iba en medio de los dos Notarios del Secreto. Por este orden llegaron a la plaza mayor en donde estaban los ministrables de la Iglesia, acompañados de los atabales y trompetas de la ciudad. Acto seguido tocaron y repicaron las campanas de la iglesia mayor y allí se dio el primer pregón y prosiguieron como siempre se había hecho. En el mismo orden marcharon hasta la Puerta de Valencia a donde les salió a recibir el convento de San Francisco. Una vez que habían llegado al lugar de costumbre, pusieron sus cruces para posteriormente dar un pregón, ordenando, que desde aquella hora hasta el día siguiente una vez hecha la ejecución del Auto, ninguna persona de cualquier clase o condición, podía llevar armas ni andar a caballo, ni por supuesto, quitar aquella cruz del lugar de donde estaba puesta.

La Carta Acordada de 1586 establecía la regla de los Autos Particulares en cuanto a las invitaciones y al uso del estandarte, ya que esto último vincula a la publicación del Auto. Es necesario recordar que había tribunales que realizaban publicación y otros no. La publicación se efectuaba por parte del Alguacil Mayor y el Secretario. Recordemos que como en el Auto Particular no se empleaba el estandarte, éste no era llevado por los Familiares como sucedía en los Autos Generales. En los Autos de Fe Generales la publicación es el símbolo de ellos y es obligatoria. En los Autos Generales destacamos la multitudinaria asistencia de público y autoridades a ellos, donde están personificados los estamentos y organismos.

\section{Procesión estandarte y bajada Cruz Verde del tablado}

La víspera del Auto por la tarde era el día señalado para la procesión de la Cruz Verde, situándose delante de ella los soldados de la Zarza (símbolo de la redención), seguían después los Familiares ${ }^{11}$ de

11 Familiares de la Inquisición: También llamados Familiares de la Fe. Fueron servidores del Santo Oficio que auxiliaban a los funcionarios de la Inquisición participando directamente en las persecuciones o arrestos. Proporcionaban un aparato de información y espionaje, a modo de un cuerpo de policía secreta. Su número creció 
la Inquisición que portaban el estandarte, después aparecía el personal del tribunal y a continuación las órdenes religiosas portando velas y acompañando el recorrido con cánticos (el miserere); finalmente desfilaban las autoridades municipales y las autoridades eclesiásticas, Comisarios ${ }^{12}$, Secretario, Receptor ${ }^{13}$, el Alguacil mayor ${ }^{14} \mathrm{y}$ cerrando el desfile el Fiscal.

La Relación lo detalla minuciosamente narrando que, desde la sala, se fueron a la parroquia de San Pedro de donde salieron en procesión con el estandarte del Cabildo de los Familiares y que una vez llegado a la plaza, con gran solemnidad y acompañados de la música de ministrables, junto al repique de las campanas, bajaron la

de manera exagerada en los siglos XVI y XVII, ya que disponían de privilegios jurisdiccionales, fiscales y de otra índole. Las Cortes, tanto en Castilla como en Aragón, protestaron reiteradamente por este aumento consiguiendo que se estableciese para ellos una especie de numerus clausus. De entre sus obligaciones podemos destacar: acudir a los mandatos de los inquisidores, denunciar a los sospechosos, conducir a los presos, etc. Para su nombramiento se requerían ciertos requisitos como ser casado, viudo o clérigo de órdenes menores; tener residencia en el lugar; prestar juramento antes de ejercer el cargo y no ser extranjero. Eran oficiales permanentes pero sin salario, aunque este cargo era muy apreciado porque, a pesar de no recibir compensación económica, sí otorgaba prestigio y honor y poseer fuero propio. Su misión principal era informativa.

12 Comisarios: Entre sus atribuciones podemos destacar la de controlar el territorio a su cargo, siendo necesario poseer una gran capacidad y cierta posición eclesiástica y social. En la práctica eran los jefes inmediatos de los familiares, seleccionándolos de entre los clérigos, teniendo mayor importancia que aquellos en las causas de Fe. De entre sus misiones podemos destacar las siguientes: recibir denuncias, la substanciación de las causas de Fe, la publicación de los edictos, la verificación de las genealogías de los pretendientes a cargos en el Tribunal. En zonas difíciles (puertos, fronteras), aumentaba su número como por ejemplo en la frontera de España con Francia donde se les encomendó la tarea de impedir el contrabando de armas y caballos. Cualquier persona podía acudir ante el comisario del lugar para entregar una denuncia por escrito y ante notario referente al delito de herejía. Éste procedía a las investigaciones citando a los testigos y siendo interrogados con arreglo a un formulario establecido. La información se enviaba al Tribunal. También podían detener a los sospechosos si existían abundantes pruebas o se sospechara que podían huir.

13 Receptor: Era el encargado de la hacienda del Santo Oficio. Realizaba los secuestros de bienes, conjuntamente con el alguacil y el notario de secuestros. Representaba a la corona, ya que correspondía a ésta la disposición de los bienes confiscados. Su nombramiento era realizado por el rey pero dependía directamente de los inquisidores, sin cuya decisión no podía realizar ninguna acción.

14 Alguacil Mayor: Tenía como misión el arresto de las personas mandado por los inquisidores. En su realización iba acompañado del Receptor, del Secretario del Secuestro y de Familiares. Tenía facultad para solicitar y recibir el apoyo de las autoridades civiles. Velaba por la seguridad de los detenidos y evitaba que éstos, no se comunicaran con otras personas excepto las autorizadas por los inquisidores. En la escala de funcionarios subalternos, el alguacil tenía la categoría más importante junto con el notario del secreto. 
Cruz que la noche anterior había sido puesta en el tablado del Santo Oficio. Acompañaban a la procesión de Familiares con su estandarte, algunos clérigos que para tal efecto habían sido invitados, de los llamados cristianos viejos. La Cruz fue bajada hasta la plaza mayor, acompañando a los clérigos, por una compañía de soldados compuesta de más de 200 arcabuceros, los cuales iban disparando todo el camino. Tras ellos iban los molineros que llevaban 16 caballos o acémilas cargadas de leña en forma de ramas y algunos soldados con arcabuces y partesanas ${ }^{15}$ en su guardia.

\section{Misa y asistentes al Auto de Fe}

Una vez llegados al lugar donde se iba a realizar la celebración del Auto, comenzaba la misa que duraba hasta la noche. El sermón iniciaba el Auto y a continuación se producía el juramento de todos los asistentes de luchar contra la herejía a favor del Santo Oficio. Posteriormente se leían las sentencias, llamando uno a uno a los reos. Acto seguido se procedía a la relajación con la entrega de los reos a la justicia seglar para su muerte por quema en la hoguera, garrote u horca. A continuación se celebraba la abjuración de los reconciliados en la que los reos con velas en las manos y de rodillas ante el altar oían del Secretario la abjuración en forma de levi o vehementi. Después el Inquisidor realizaba algunas oraciones y se encendían las velas de los reos. Una vez terminado el Auto los condenados volvían a la cárcel del Santo Oficio para cumplir su pena.

Hay que distinguir en este apartado dos aspectos fundamentales, si la asistencia se produce cuando existan relajados, o sin ellos, ya que es diferente en cada caso con respecto a las autoridades concurrentes y el lugar de celebración.

La Relación que estudiamos, nos refiere que el sábado 6 de agosto, a las cinco de la mañana, se celebró una misa en el Santo Oficio y posteriormente, fueron entregadas varas para regular la procesión, a 10 o 12 personas seleccionadas, de las llamadas honradas de entre los Familiares. Esta comitiva entró en la iglesia sobre las seis de la mañana, una vez que había habían acabado la misa. Las autoridades civiles, Corregidor y Alcalde Mayor entraron en la sala y se sentaron en bancos que estaban puestos alrededor de las paredes, mientras que el Corregidor y Alcalde Mayor, lo hicieron en el escaño que estaba junto al altar, sitio reservado a los Inquisidores. Luego llegó

15 Hoja de lanza grande y recta llegando hasta los dos metros, que era ancha por la base y con filo por ambos lados. 
el marqués de Cañete y tomó asiento en el mismo escaño, junto al Corregidor y Alcalde mayor. A continuación llegó el obispo que por entonces era don Gómez Zapata ${ }^{16}$ tío del conde de Barajas, presidente del Consejo Real y en llegando su señoría se levantaron todos y estuvieron así en círculo hasta que salieron de allí.

\section{El escenario del Auto de Fe General}

Varias son las normativas que contemplan esta materia, aunque no hay nada que determine de manera clara y reglamentaria este tema dejando casi un vacío dando lugar a que se determine más por la voluntad de los tribunales que por la norma. De ellas podemos destacar:

La Instrucción 77 de $1561^{17}$ de Toledo no establecía el lugar de celebración del Auto de Fe, por consiguiente, el lugar donde se puede efectuar, es cualquier sitio.

La Cédula de 1587 instituía la decisión de dejar a voluntad de los inquisidores el lugar de conmemoración.

Sin embargo, respecto a Cuenca, la Carta Acordada de 1537 dirigida al tribunal de Cuenca establece que: habiendo personas relajadas se celebre el Auto de Fe en la plaza y no en la Iglesia ${ }^{18}$. Los Autos ulteriores a esta Fecha en el tribunal conquense siguen la regla establecida de forma que cuando existen relajados se llevan a cabo en la Plaza Mayor o de Santa María del Mercado y cuando no existan se celebre en la catedral. El lugar de celebración de la mayoría de los Autos de Fe en Cuenca es la plaza de la iglesia.

\section{6.a) Elementos que componen el escenario. El Tablado y el Quemadero}

El tablado, cadalso o catafalco, denominación común, se encomienda al carpintero que lo ha de construir, el día que se produce

16 Gómez Zapata Osorio, nació en Villaescusa de Haro en 1587 y murió en Madrid. Hijo del IV señor de Barajas, Juan de Zapata y de Leonor Osorio Coello. Estudió en Salamanca, fue canónigo de Toledo miembro del Consejo de Indias, obispo de Cartagena y de Cuenca. Sobre este personaje pude verse: Trifón MUÑOZ y SOLIVA, Noticias de todos los Ilustrísimos señores obispos que han regido la diócesis de Cuenca, pp. 234-237. Y Juan Pablo MÁRTIR RIZO: Historia de la muy noble y leal ciudad de Cuenca, pp. 198-199.

17 AHN. Inquisición. Libros 498, 500 y 1270.

18 AHN. Inquisición. Libro 1231, p. 160. 
el pregón. Este elemento se construye tanto en los Autos Generales como en los Particulares, exceptuándose como es lógico de pensar, cuando su resolución se produce en el interior del edificio del Santo Oficio, es decir en la Sala del Tribunal. Su financiación no está definida claramente, corriendo el gasto unas veces a cargo de la Inquisición y otras a cargo del Ayuntamiento. En el siglo XVIII esta cuestión deja de preocupar con motivo de la decadencia del Auto de $\mathrm{Fe}$, incluida la propia institución que lo organiza y los tablados se sustituyen por sólo bancos y sillas resultando menos esplendorosos y con menos asistencia de autoridades. Y más cuando observamos en este siglo que los celebrados en la sala del tribunal consisten en la misa y la lectura de las sentencias sin más asistencia que el tribunal.

En este caso que estudiamos descubrimos que en el Tablado de los penitentes había un tránsito ${ }^{19}$ de 20 pies de largo y 10 de ancho. El tablado de los penitentes tenía el ancho del cadalso y 30 pies de largo. A la mano derecha, que eran las espaldas hacia la acera de casas que estaban en el límite con la iglesia mayor, estaban hechas las gradas en donde se sentaron los penitentes. En el resto del tablado estaban sentados los religiosos y Familiares. En el mismo tablado estaban puestas, a manera de barandilla o tabladillo, tres gradas a donde se colocaban los penitentes de quienes se leían las sentencias. Este tabladillo estaba en medio al final del tablado hacia el cadalso y al lado de donde estaban los cargos municipales, los cuales, tenían su tablado junto al de los penitentes, de suerte, que estaban enfrente de las gradas de ellos. Por precaución, fue colocado un toldo para cubrir el tablado de los penitentes. Estaba el tablado de los penitentes tres gradas y aún cuatro, más bajas que el cadalso de los Inquisidores. Conforme al orden en que estaban sentados los oficiales, volvían algunos de ellos a la casa del Santo Oficio. Una vez que llegaba el Alguacil, los penitentes comenzaban a salir por el orden y con las insignias que los inquisidores les tenían asignado. Junto a cada penitente estaban dos Familiares, colocándose el penitente en medio de ellos, llevando los Familiares delante la cruz de la parroquia, cubierta con un velo negro y con ella iban los clérigos de la parroquia y tras ellos los penitentes.

La Relación nos informa que en primer lugar, iban 2 estatuas y marchando tras las estatuas, 31 personas por diversos delitos y tras de ellos, 3 mujeres reconciliadas, por último, iban 2 relajados. Estaba colocada y formada, desde la calle de la puerta de la Inquisición hasta el tablado, la compañía de soldados arcabuceros que hacían calle y lugar a los penitentes. Llegaron de esta manera los condena-

19 Pasillo. 
dos y subieron a su tablado, sentándose en las gradas y colocando las estatuas en las esquinas de las gradas y en la última grada se sentaron los relajados junto a sus confesores y los demás penitentes que cupieron. ${ }^{20}$. Hay que señalar, que en los Autos Generales, el tablado es mucho mayor que el que se construye en los Autos Particulares.

El quemadero ${ }^{21}$ o brasero que se construye por la autoridad civil pero con cargo al Santo Oficio, aunque esta institución elude efectuar el pago siempre que puede. A él son llevados los relapsos arrepentidos, los no relapsos pertinaces, los herejes pertinaces y relapsos, y también los herejes negativos y rebeldes. Es el lugar donde son quemados los condenados al fuego, ya fuera en persona o bien en estatua, y por regla general, estaba situado fuera de la población. Normalmente, consistían en un pilar con un montón de leña, sujetando al reo al pilar, o simplemente consistían en montones de leñas.

En esta Relación se nos dice que fueron entregados los relajados desde el cadalso, al exponer que cuando bajaron del cadalso los relajados, fueron entregaron a la justicia secular que allí estaban en recaudo para llevarlos al quemadero, yendo en su acompañamiento la Compañía de soldados$^{22}$.

\section{La procesión de las cruces, de los reos y autoridades}

La jornada del Auto de Fe se iniciaba con la procesión de los penitentes, que recorrían las calles en dirección al lugar exacto donde se iba a realizar el Auto. La procesión era anunciada por las campanas de la catedral y las iglesias del lugar de celebración. Al desfile salían en primer lugar los condenados por este orden: se iniciaba con los relajados, luego los reconciliados y detrás los penitentes. El estandarte solía llevarlo el Fiscal y la comitiva la cerraba el Inquisidor más antiguo, con el obispo a su derecha y a su izquierda generalmente el presidente de la Chancillería.

Las Cartas Acordadas, eran las encargadas de regular las procesiones de los reos y la asistencia de autoridades. También, regían el orden o preminencia de autoridades eclesiásticas y civiles. El orden

20 ADC. Inquisición. Libro 339, f. 225.

21 Pérez Galdós nos describe el quemadero de la siguiente forma: Voy a contar cómo fue el quemadero, el inhumano que tantas vidas infieles consumió en llamas; que a unos los traspasó los hígados con un hierro candente; a otros los puso en cazuelas bien mechados, y a los demás los achicharró por partes, a fuego lento con rebuscada y metódica saña. PEREZ GALDOS, B., Torquemada en la hoguera, Madrid, 1971.

22 ADC. Inquisición. Libro 339, f. 225 
de los reos en las procesiones es la inversa que el de las autoridades, es decir, van de menor a mayor. Todo gira sobre tres órdenes, los presos que están en la cárcel, los fugitivos y los difuntos.

En el desfile, en primer lugar, van los absueltos. Existen dos clases de absolución, los absueltos pura y llanamente (cosa infrecuente) y los absueltos ad cautelam en los que no se ha podido probar el delito y se les absuelve de forma preventiva.

En segundo lugar están los penitenciados que sufren la abjuración en sus tres tipos: formali, vehementi y levi. Van acompañados por dos familiares. Suelen llevar la cabeza descubierta sin capa y sin cinto, soga de esparto al cuello e incluso coroza y vela verde o amarilla según el delito.

En tercer lugar tenemos a los reconciliados que es el hereje convicto y confeso con deseo de volver a la Iglesia y abjura de sus errores, sin existencia anterior de sospecha ni abjuración y al que se le confisca sus bienes. Llevan Sambenito con dos aspas o media, coroza amarilla, soga y vela.

En cuarto lugar figuran los relajados que es el hereje reconciliado y vuelto a reincidir en la herejía y se les relaja al brazo secular. Van acompañados de dos familiares y dos religiosos. Suelen llevar casaca y coroza con llamas, soga y vela verde.

En las procesiones van también los huidos para los que preparan unas estatuas con inscripciones en pecho y espalda con el nombre, delito y el nombre de fugitivo. De igual forma desfilan también los muertos y que son llevados sus huesos en cajones situados detrás de las estatuas.

En cuanto a las autoridades asistentes y acompañando a la cabecera, el Inquisidor más antiguo se suele situar a la derecha, después el obispo y a la izquierda el Corregidor, un poco más adelante el segundo Inquisidor y siguiéndoles, marqueses, ordinarios y procuradores.

El comienzo del desfile y el orden que debían llevar los componentes del mismo, nos lo describe esta Relación de forma magistral diciendo, que una vez que hubo llegado el aviso de como la iglesia mayor salía en procesión como acostumbra a recibir al Santo Oficio, salieron todos en este orden:

Primero. El Inquisidor Ximénez de Reinoso por ser el más antiguo, en medio del Obispo y del Corregidor, llevando al Obispo a la mano derecha y al Corregidor a la mano izquierda, que era Jerónimo de La Bastida, caballero de Valladolid. 
Segundo. A continuación el Inquisidor don Antonio Zapata, llevando a su mano derecha al marqués de Cañete y a la izquierda al Provisor, que era el licenciando Bernardino Rodríguez.

Tercero. Luego iban el administrador de Santiago, que era el licenciado doctor Grima, llevando a su mano derecha al Alcalde Mayor.

Cuarto. Inmediatamente iba el licenciado Ballesteros, Fiscal de la Inquisición, con el estandarte del Santo oficio y llevaba a su mano derecha al licenciado Calatrava, Juez de bienes y a la izquierda al licenciado doctor Moreno, Abogado del Fisco.

Quinto. Posteriormente iba el licenciado Muñoz, canónigo de Cuenca, Consultor del Santo Oficio en medio del licenciado Villanueva a mano derecha y el licenciado Juan Noguerol, Consultor del oficio, y allí junto con ellos, iba Simón Ángel, Notario del secreto. Los demás oficiales permanecían en el Santo Oficio. El Alguacil iba en medio tutelando la procesión, por estar indispuesto Hernán Guerra que al presente era el Alguacil. La vara fue llevada por el Familiar Alonso de Resa, haciéndolo por mandado de los Inquisidores.

Sexto. Después de los Consultores iban las autoridades civiles de Cuenca por orden de antigüedad.

De esta manera salieron del Santo Oficio y fueron la calle abajo hasta que se encontraron con la procesión de la Iglesia que fue un poco más arriba, enfrente de la parroquia de San Nicolás. Y en llegando el estandarte adonde estaba la Cruz de la Iglesia, se volvió la Cruz hacia la Iglesia y con ella los beneficiados por su orden, de suerte que fueron a quedar los dos más antiguos al lado del estandarte, entonces, el Juez de bienes y Abogado se ponían detrás y de esta manera se iba hasta emparejar con las gradas de la iglesia adonde se quedaban todos los beneficiados. Entonces, entraban en la iglesia y las autoridades civiles iban a su tablado. Al llegar a la puerta del cadalso, se despidió el Corregidor, marqués y el Alcalde Mayor y se fueron con las autoridades civiles de Cuenca. Los demás subieron al cadalso a donde se sentó el Obispo en medio de los inquisidores, teniendo el más antiguo a la mano derecha y al Corregidor de aquel lado, y de la otra al Inquisidor más nuevo con el Administrador de Santiago. En la segunda grada estaban el Fiscal y los Consultores y también, algunos prelados de las órdenes y gente principal de manteo y bonete, estaban en el lado derecho. En la parte baja, estaba un banco puesto de espaldas, para el Alguacil y Receptor. En el izquierdo había otro con un bufete y sobremesa a donde estaban los Notarios del Secreto y secuestros ${ }^{23}$.

23 ADC. Inquisición. Libro 339, f. 223. 


\section{Pronunciación del sermón y lectura del edicto}

En Cuenca por lo general, el encargado del sermón de la Fe, era el P. Prior del convento de San Pablo. Una vez acabado el sermón, el presidente del festejo, tocaba una campanilla, subiendo a continuación al púlpito que estaba generalmente al lado derecho del cadalso. Allí, el Notario del Secreto del Santo Tribunal hacía la protesta de observanda fide, obediendo Sancto Oficio inquisitionis,

En lo referente al sermón, la Relación nos dice, que en el interior del convento de San Pablo, habiendo tomado la bendición del Obispo, predicó casi una hora, que vino a ser desde las 7:30 a las 8:30 horas. Una vez acabado el sermón, que fue dado desde el púlpito que estaba situado a mano derecha del cadalso, de manera que miraba hacia los Inquisidores, autoridades civiles y penitentes, fue leído un edicto como era costumbre en semejantes acontecimientos y días ${ }^{24}$.

\section{Lectura de sentencias}

De madrugada, el Inquisidor, el Secretario y el Alcaide ${ }^{25}$, se encargaban de la imposición de las insignias (sogas, bozales) a los reos según su pena. A los reconciliados se les entregaba un sambenito (rojo con la cruz de San Andrés) y velas, a los relajados ${ }^{26}$ se les ponía un sambenito (con llamas y diablos) y la coroza correspondiente, y se les daba confesor.

En el caso concreto, por esta Relación, se nos describe que cuando se acabó el sermón, comenzaron a leer las sentencias, empezando por un blasfemo y tras proseguir diversos asuntos, fueron las últimas tres mujeres reconciliadas. Acabadas de leer las sentencias, el Inquisidor Jiménez de Reynoso, se vistió una sobrepelliz ${ }^{27}$ y asistiendo a su lado algunos clérigos, comenzó la reconciliación, respondiendo a canto de órgano los cantores de la Iglesia que dijeron un veni santies-

\footnotetext{
24 ADC. Inquisición. Libro 339, f. 224.

25 Alcaide: Su misión era el control de las celdas y también el cuidado de los presos. Se encargaba de recibir a los detenidos por los alguaciles, debiendo registrarlo en el correspondiente libro y anotar cuidadosamente la ropa que llevaban consigo los reos así como las cosas que les eran proporcionadas durante su prisión. Estaban obligados a mantener incomunicados a los presos. Cuando estos comparecían en la sala de audiencias eran conducidos por él, quien también se encargaba de su retorno, salvo disposición en contrario de los inquisidores

26 Relajación al brazo secular: Entrega del procesado condenado a muerte al verdugo de la jurisdicción ordinaria para su correspondiente ejecución.

27 Sobrepelliz: vestidura eclesiástica de lino parecida al alba pero más corta y que se lleva sin ceñir al cuerpo.
} 
piritus y miserere mei. Uno de los penitentes que había de abjurar de vehementi, juró allí mismo el juramento. Terminada la reconciliación se volvió el Inquisidor a su lugar y se leyeron las sentencias de las dos estatuas y por último la de los relajados. Una vez acabada la lectura, se volvieron los penitentes a la Inquisición por el mismo orden y de la misma manera que fueron ${ }^{28}$.

\section{Regreso de la procesión a la casa de la Inquisición}

El retorno procesional, según la Relación, se produce cuando bajaron el Obispo y el Inquisidor, mientras, a la puerta del tablado volvieron a juntarse el Corregidor y el marqués de Cañete, volviendo a la Inquisición por el mismo orden que habían ido y llegando, una vez dentro del zaguán de la casa, se despidieron y se fueron cada uno para su casa. Mientras tanto, aquella misma tarde, salieron algunos de los condenados que habían de ser azotados. y al día siguiente por la tarde, los que restaban ${ }^{29}$.

\section{Terminación del Auto}

En el caso que nos ocupa se relata que lo narrado, es lo que ocurrió en el mencionado Auto de Fe de 6 de agosto de 1583. Dicho Auto de Fe finalizó a la 1,30 horas del jueves del mediodía, exponiendo que comenzó a salir el Santo Oficio de la Inquisición a las 6,30 de la mañana ${ }^{30}$.

\section{CONCLUSIONES}

Este trabajo pretende analizar los complejos aspectos sociales, religiosos y políticos a la vez que es necesario destacar el aspecto festivo que encerraba el Auto de Fe en esa época. Requisitos imprescindibles para la celebración del mencionado Auto, eran una buena organización para poder dar ese espectáculo religioso que se pretendía dar a conocer a los asistentes al mismo y motivado por el elevado costo. Otro de los requisitos necesarios eran los fines que se querían obtener con estas celebraciones, cuales eran mostrar a los herejes y contrarios a la fe católica y así permitir la comunión de la Iglesia con

28 ADC. Inquisición. Libro 339, f. 225

29 Íbid., f. 226.

30 Íbidem., f. 226. 
los fieles. La Inquisición se reafirma desde su creación en 1478, mediante los famosos Autos de Fe. Durante el siglo XVI, la Inquisición tenía en España un peso considerable y tanto en este siglo como en los posteriores los Autos de Fe fueron una fiesta popular en donde la gente disfrutaba en la calle viendo al hereje, reafirmando al mismo tiempo su fe católica.

Qué es el Auto de Fe preguntaremos, pues ni más ni menos que la exaltación de la $\mathrm{Fe}$, la exaltación de la unidad religiosa. Es el acto culminante que usa la Inquisición para conseguir el punto final de la publicidad de los símbolos y lugares usados para ello. El Auto de $\mathrm{Fe}$, se compone generalmente de una procesión donde desfilan las autoridades religiosas y civiles, junto a los reos, donde se portan 2 cruces. La una es verde y se ubica en el tablado donde se desarrolla el Auto de Fe. La otra es blanca y se situará en el quemadero donde serán quemados en la hoguera los reos condenados a relajación por parte de la autoridad secular, ya que la Inquisición no mata, lo hace la autoridad civil.

En Cuenca, cuando los Autos son Públicos y solemnes, la Cruz Verde se sitúa generalmente en la Plaza Mayor. De ahí la publicidad que quieren darle, ya que en otro sitio más recóndito, lo vería poca gente. Cuando los Autos son Particulares, donde no hay relajados, se celebran en la Iglesia de San Pedro, es decir, no necesitan de publicidad, ni asistencia de autoridades civiles, sino solamente las inquisitoriales. La Cruz Blanca, se sitúa en el quemadero, que son los aledaños de San Francisco, hoy jardines de la Diputación, donde son llevados los relajados, bien en persona, bien en efigie.

En toda actuación inquisitorial, sin excepción, rige el principio del secreto, es decir, los acusados quiénes los denuncian, quiénes son los testigos, de qué delito se le acusa y al terminar el proceso, deben guardar secreto de todo lo actuado dentro de juicio y fuera de él y prometiendo no decirlo a nadie. Qué se pretende con ello, esencialmente, que las ideas religiosas no sean conocidas por terceras personas y que haya publicidad de las mismas y por tanto, lograr que no sean propagadas. ¿Cuál es la contradicción? Sencillamente, si con el secreto pretende la Inquisición que no se difunda las ideas religiosas contrarias, en el Auto de Fe se describe con todo detalle la doctrina por la que ha sido condenado el reo. Ejemplo: condenado por judaizante, por morisco, por luterano, etc. Eso logra que la gente que no conocía estas corrientes, las oiga en ese acto, cosa que antes no sabía y que gracias al secreto usado por la Inquisición, no las conoce. 


\section{APÉNDICE}

\section{EL AUTO GENERAL DE FE DE 6 DE AGOSTO DE 1583 EN EL TRIBUNAL DE LA INQUISICIÓN DE CUENCA}

ADC., libro 339, ff. 222-225.

Auto General del año 1583. Relación del orden que se tuvo en el auto que se celebró a 6 de agosto, día de la transfiguración, año de 1583.

Se escribió al Consejo pidiendo licencia como tienen ordenado y mandaron se enviase razón de que causas, cuantas, y de qué calidad estaban despachadas, se les envió en suma muy breve las que había y respondido se publicase para el día que quisiesen y avisasen de ello como les estaba mandado y así miércoles 26 de julio enviando a las dos de la tarde a dar cuenta de cómo se quería publicar con el fiscal al obispo y de allí al cabildo, y con el alguacil al marqués y marquesa de Cañete, y con el receptor a la ciudad por ser Regidor que otras veces suele y el alguacil a la ciudad y receptor al marqués. Y venidos fiscal y alguacil y receptor de sus embajadas a las cuatro de la tarde salieron del oficio más de 20 familiares a caballo que estaban apercibidos desde la mañana y últimamente el alguacil en medio de los dos notarios del secreto y por este orden llegaron a la plaza mayor a donde estaban los ministrables de la Iglesia respecto y atabales y trompetas de la ciudad y tocaron y repicaron las campanas de la iglesia mayor y allí se dio el primer pregón y prosiguieron como siempre se acostumbra.

Viernes 5 de agosto a las tres de la tarde acudieron al oficio los familiares de él adonde el señor Inquisidor Jiménez de Reynoso les habló y encomendó el buen orden y sosiego y señaló cuatro familiares que otro día siguiente guardasen el tablado y puerta y les dijo acudiesen otro día bien de mañana y se les darían varas a algunos para que gobernasen la procesión. Asimismo encomendó a tres o cuatro de ellos gente honrada estuviese el día siguiente en las entradas de la plaza para no dejar entrar en ella a ninguna persona a caballo ni con armas conforme al pregón que se da según abajo se dirá. Desde la sala se fueron a la parroquia de San Pedro de donde salieron en procesión con el estandarte del cabildo de los familiares y llegaron a la plaza y con gran solemnidad y música de ministrables y más y repicaron de las campanas bajaron una cruz que la noche antes se pone en el tablado del Santo Oficio y acompañando la misma procesión de familiares con su estandarte y algunos clérigos que para ello 
se convidan cristianos viejos, la llevaron por la plaza abajo viniendo consecutivamente de los clérigos una compañía de soldados de más de 200 arcabuceros disparando todo el camino, después de ellos iban los molineros que llevaban 16 caballos o acémilas cargadas de leña muy enramadas y algunos soldados con arcabuces y partesanas en su guardia. Por este orden van hasta la puerta de Valencia a donde les sale a recibir el convento de San Francisco y llegados al lugar ordinario pone en sus cruces y luego se da un pregón que desde aquella hora hasta otro día hecha ejecución del auto que ninguna persona de cualquier calidad que sea, pueda traer armas ni andar a caballo, ni quitar aquella cruz del lugar adonde la ponen.

Habiendo de haber relajados aquella noche se les hace saber y se les da confesor.

Sábado 6 de agosto a las cinco de la mañana se dijo misa en el oficio y se dieron varas para gobernar la procesión 10 o 12 personas de las honradas de entre los familiares, en la iglesia entraron a hora que a las seis habían acabado su oficio. La ciudad y Corregidor y Alcalde Mayor vinieron a la sala y se sentaron en bancos que estaban puestos alrededor de las paredes y el Corregidor y Alcalde Mayor en el escaño que está junto al altar no estaba ninguno de los señores inquisidores porque andaban en el secreto dando orden en cosas que se ofrecía. Luego vino el marqués de Cañete y se asentó en el dicho escaño juntamente con el dicho corregidor y alcalde. Luego vino el obispo que era don Gómez Zapata tío del conde de Barajas, presidente del Consejo Real y en llegando su señoría se levantaron todos y estuvieron así en ruedo hasta que de allí salieron y en llegando aviso de como la iglesia mayor salía en procesión como acostumbra a recibir el oficio, salieron todos en este orden:

Inquisidor Ximénez de Reinoso más antiguo, en medio del obispo y corregidor, llevando al obispo a la mano derecha y al corregidor a la mano izquierda, qué era Jerónimo de La Bastida, caballero de Valladolid. Luego el inquisidor don Antonio Zapata, llevando a su mano derecha al marqués de Cañete al provisor que era el licenciando Bernardino Rodríguez. Luego iban el administrador de Santiago que se dice el licenciado doctor Grima llevando a su mano derecha al alcalde mayor. Luego iba el licenciado Ballesteros, fiscal con el estandarte del oficio y llevaba a su mano derecha al Licenciado Calatrava, juez de bienes y a la izquierda al Licenciado doctor Moreno, abogado del Fisco. Luego iba el licenciado Muñoz, canónigo de Cuenca, consultor del Santo Oficio en medio del Licenciado Villanueva a mano derecha y licenciado Juan Noguerol, consultor del 
oficio y allí junto con ellos iba Simón Ángel, notario del secreto. Los demás oficiales quedaban en el oficio. El alguacil iba el medio rigiendo la procesión y por estar indispuesto Hernán Guerra que al presente es alguacil, llevó la vara por mandado de los señores inquisidores Alonso de Resa familiar. Luego inmediatamente a los consultores iba la ciudad por su orden de antigüedad de esta manera salieron del oficio y fueron la calle abajo hasta que encontraron con la procesión de la Iglesia que sería un poco más arriba de enfrente de la parroquia de San Nicolás y en llegando el estandarte adonde está la cruz de la Iglesia, se vuelve la cruz hacia la Iglesia y con ella los beneficiados por su orden de suerte que vienen a quedar los dos más antiguos al lado del estandarte y el juez de bienes y abogado se ponen detrás y de esta manera se va hasta emparejar con las gradas de la Iglesia adonde se quedan todos los beneficiados y se entran en su iglesia y la ciudad se va a su tablado y al llegar a la puerta del cadalso se despide el corregidor y marqués y alcalde mayor y se van con la ciudad. Los demás suben al cadalso a donde se asentó el obispo el medio de los inquisidores, teniendo el más antiguo a la mano derecha y al corregidor de aquel lado y de la otra al inquisidor más nuevo con el administrador de Santiago y en la segunda grada estaban el fiscal y los consultores y en todo aquello algunos prelados de las órdenes y gente principal de manteo y bonete al lado derecho en lo bajo estaba un banco de espaldas para el alguacil y receptor en el izquierdo otro con un bufete y sobremesa a donde estaban los notarios del secreto y secuestros y tenían las sentencias y cruz y campanilla y libro de abjuraciones y reconciliación del cadalso. Al Tablado de los penitentes había un tránsito de 20 pies de largo y 10 de ancho. El tablado de los penitentes tenía este ancho del cadalso y 30 pies de largo a la mano derecha que es las espaldas hacia la acera de casas que estaban frontero de la Iglesia mayor estaban hechas de gradas en que se asentaron los penitentes y en lo demás del tablado estaban varios a donde se asentaron religiosos y familiares en el mismo tablado estaba a manera de barandilla puesto un tabladillo de tres gradas a donde se ponían los penitentes de quien se leía la sentencia. Este tablado y lo estaba en medio al cabo del tablado hacia el cadalso y al lado de donde estaba la ciudad. La cual tenía su tablado junto al de los penitentes de suerte que estaban enfrente de las gradas de los penitentes. Se puso un toldo que cubría el tablado de los penitentes.

Estaba el tablado de los penitentes tres gradas y aun cuatro más bajas que el cadalso de los inquisidores por la forma que esta dicha y sentados vuelven los oficiales digo algunos a la casa del oficio y en llegando el alguacil, los penitentes comienzan a salir por el orden y 
con las insignias que los inquisidores tienen mandado, llevando a cada penitente dos familiares en medio y llevando delante la cruz de la parroquia cubierta con un velo negro y con ella los clérigos de la parroquia y tras ellos los penitentes. Lo primero iban 2 estatuas y luego 31 personas por diversos delitos y tras de ellos 3 mujeres reconciliadas y último 2 relajados. Había desde la calle de la puerta de la inquisición hasta el tablado la compañía que esta dicha de soldados arcabuceros que hacían calle y lugar a los penitentes. Llegaron de esta manera y subieron a su tablado y se sentaron en las gradas poniendo las estatuas en las esquinas de ellas y en la última se sentaron los relajados y sus confesores y los demás penitentes que cupieron y sosegada la gente. El interior de San Pablo que al presente era habiendo tomado la bendición del obispo predicó casi una hora que vino a ser desde las 7:30 a las 8:30. Acabado el sermón que fue en el púlpito de mano derecha del cadalso de suerte que miraba hacia los inquisidores, ciudad y penitente. Luego se leyó un edicto que se acostumbra en semejantes días, cuando se acabó, comenzarán a leer las sentencias comenzando por un blasfemo y prosiguiendo diversos negocios fueron últimas tres mujeres reconciliadas. Acabadas de leer el señor inquisidor Jiménez de Reynoso, se vistió una sobrepelliz y asistiendo a su lado algunos clérigos, comenzó la reconciliación respondiendo a canto de órgano los cantores de la Iglesia que dijeron un veni santiespiritus y miserere mei.

Uno de los penitentes que había de abjurar de vehementi, juró allí juramento. Terminada la reconciliación se volvió el inquisidor a su lugar y se leyeron las sentencias de las dos estatuas y últimamente de los relajados, acabadas se volvieron los penitentes a la inquisición por el mismo orden y manera que vinieron y acabado de salir del cadalso bajaron los relajados y se entregaron a la justicia que allí estaban con recaudo para llevarlos yendo en su acompañamiento la Compañía de perros. Luego se bajó el obispo e inquisidor y a la puerta del tablado volvió a juntarse el corregidor y marqués y volvieron a la inquisición por el mismo orden que habían ido y llegando y dentro del zaguán de la casa se despidieron y se salieron cada uno para su casa aquella misma tarde salieron algunos de los que habían de ser azotados y otro día por la tarde lo que restaban. Y esto es lo que pasó en el dicho auto 6 de agosto de 1583 se acabó a la 1,30 del jueves del mediodía comenzó a salir el oficio de la inquisición a las 6,30 por la mañana. 